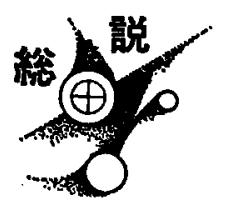

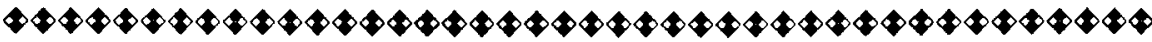

\title{
〔78〕加速器による核燃料生産および 放射性廃棄物処理の可能性
}

\author{
小 寺 正 俊*
}

（1984年 3 月15日 受理）

Possibility of Usage of Accelerators for Fertile to Fissile Fuel

Conversion and Radioactive Wastes Disposal by Incineration

By Masatoshi ODERA

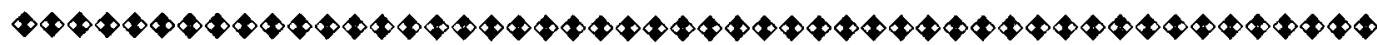

The status and prospect of the nuclear fuel production and incineration disposal of the radioactive wastes by high energy and high current accelerators are reviewed and discussed. Probable shortage of the fissile nuclear fuels of the world in the next century suggests necessity of study of new nuclear energy options. Conversion of fertile materials to fissile by the accelerator-bred neutrons is considered as one of the candidates. Its scientific feasibility has been already demonstrated for more than 30 years since. However, its reliability and cost in operation as a large scale plant must be examined carefully by systematic studies.

Bombardment by high current and high energy proton beams is also considered as a probable means of disposal of the radioactive wastes of which accumulation is one of arguments against nuclear power plants. Both proposals need almost the same $R$ \& D studies and can share research budget and manpower in common, to a considerable extent. Japan with her poor energy resources, should begin such studies of her own as early as possible on relatively modest levels at least.

KEYWORDS: fissile fuels, nuclear fuels, incineration disposal, conversion, fertile material, accelerator-bred neutrons, feasibility, high energy proton beams, radioactive wastes, energy resources

\section{I . まえがき}

最近のエネルギー需給のゆるみから，わが国のエネ ルギー資源の負しさに対する危機感が減退し，財政の 切䚾めもあって，いくつかの新エネルギー源開発努力 のスローダウンが伝えられている。るらろん，非常事 態の際に採択された方策は状況が好転し，醒めた目で 見られれば，その現実性の評価が変化する場合がある のは当然である。

わが国の場合，巨大技術の開発は，非常事熊の緊迫 感と，国外ではすでに開始されているといった事熊に 促されてスタートした場合が多い。その場合，基碄的 検討の積上げよりはいかに早く㬰用機を作るかに重点 が就かれ勝ちで，その後に応用的研究が開始され，場 合により基礎研究にまでさかのぼる。この方式は資金 効率が高く，それなりに成功した面があったことは否 めないが，常にそのよらな偾倖が続き得るか否かは疑 わしい。そして、エネルギー源に関しては不運という
言葉ではすまされない影響があるのであってみれば， 短期的な情勢に惑わされることなく，俪見を排除して 複数の選択肢の検討が継続してなされることが望まし いことはいうまでもない。もちろん長期的計画のもと に核融合炉，高速増殖炉をはじめ各種の研究が進めら れて扣り，また現在はェネルギ一問題と無縁の研究か ら新しい可能性が生まれてくることもあり得よう。そ れらを認めた上でな陉待点で「加速器による核然 料生産および放射性廃㲤物処理」方式は検討に值する と考えるので，その概要と現状を紹介したい。

加速器により中性子を発生させ，これを捕獲させて 非分裂性の重元素(親核物質)を核分裂性物質八転換す る方法については，原理的にも実際の手段についても すでに国外で研究が行われ，エネルギーの収支につい ては充分にプラスであるとされているが，実用性と释 済性についてはさらに実証的研究が必要と思われる。 これらの点の見通しが肯定的ならば，原理的な困難は * 理化学研究所(Inst. of Phys. Chem. Res.) 
ない方式であるので，21世紀初頭から半ばにかけての わが国のエネルギー源に明るい材料を一つ加えること ができることとなる。この方式の先駆的試みとして， 低エネルギー,大電流の重陽子加速器による実証試験 が30年前に米国リバーモア研究所で行われ，核然料の 大量生産が可能であることが確認されている(1)。

第 1 図は, 1982年の OECD の核エネルキ゚ー資源調查 報告からの転載である(2)。自由主義諸国の人口動態, 産 業動向，探鉱統計からの推計で，実線は現在の軽水炉 によりUを消費し，核然料の再処理利用をしない場合 の必要量である。景気あるいは生活水準の動向，特に 人口の多い発展途上国のそれの推定に大きな不確定珄 があり，最大需要(High)と最低(Low)の間には大きな 閭きがある。1点鎖線は現存のみならず，地質図から 期待し得るU钩の新規開発の推定量も含めた採掘可能 量で，需要量が最低の場合でも，2010年以前に需要に 供給が及び得なくなることを示している。そのことは 核ェネルギー利用の開始当初から知られており，再処 理による Pu 抽出とそれを使用する高速增殖炉(FBR) の開発が進められて来た。図の破線は FBR が丰用化 されて核エネルギー体系に組み込まれた時のU需要で ある。問題は FBR が実用化されても需給の不均衡が 生じ得ることである。FBR は建設後しばらくの期間 は核然料の需要者であって生産者ではない。総合した

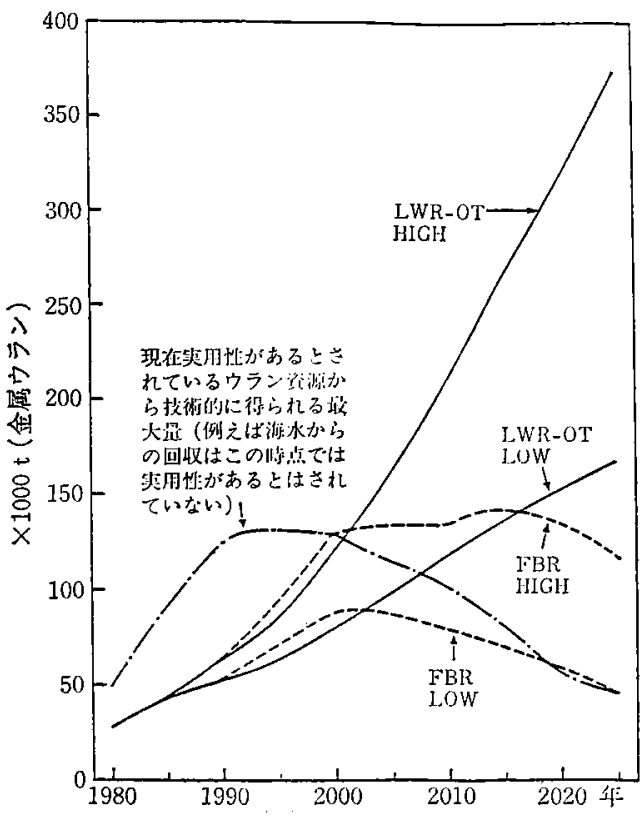

IWR-OT: Light Water Reactor-Once Through 第 1 図 自由主義圈のU需要推計 ${ }^{(2)}$
需要が High の時は2000年以降長期にわたる不足が続 く。Low の場合62020年以前にェネルギー資源供給 に関して緊張状態が発生する可能性がある。核エネル ギー資源についても自給の困難なかが国が不利な立場 に立たされる場合もあり得よう。

以上の核エネルギー資源の状況から見ると，核融合 炉, 高速増殖炉の開発が現在の計画に沿って進行して わ，今世紀末から21世紀にかけてのエネルギー問題の 発生之，資源価格の急上昇の可能性は大きいと思われ る。加速器による核然料の生産はその事態に対する一 つの安全保障策となり得ると考えられている。もらろ ん, この方式の㬰現には核兵器転用の困難な方式をと ることと, 安全性と信頼性が準備研究により確認され ていることが前提で，わが国もその検討作業を早急に 開始することが望まれる。

さらに補足すると，この方式には次のよらな長所が あるとされている。

（1）核然料の生産能率が高く，加速器施設 1 基で数 基〜 10数基の 100 万W 級発電炉の運転を賄えよ う。発電师の数は炉型により異なる。

（2）連鎖反応は生じないので，入射ビームを断つこ とにより，機能は直ちに停止し，いわゆる核暴走 の問題がない。

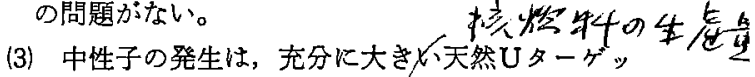
ト体系に対しては $1 \mathrm{GeV}$ 陽子/ 1 個当り100個に達 すると考えられているが，実祭の有限な大ささの 体系ではこれょり少なくな节。しかし，それでも 生成する核分裂原子核 1 個当りの発生熱量が軽水 炉あるいは高速増殖炉の場合より少ないから，冷 却条件が同じであれば中性子柬を大きくできる。

(4) また核燃料の生産量に対する放射性同位元素の 発生量が少ないから, 多量の発電炉用然料生産に おける廃率物発生量を少なくできる。

(5) Thをブランケット領域に扣くことにより，従 来核然料として使用されなかった Thをエネルギ 一資源に利用できる可能性がある。Thから得ら れる ${ }^{23} \mathrm{U}$ は従来型炉を含む熱中性子灯の燃料と しても特性が優れている。

(6) ターゲットシステムの構成とビーム特性の選び 片より，入射エネルギーの数倍の熱量を発生す る。これを30〜40\%の効率で電力に変えることが できれば，この施設で使用する電力の大部分を賄 らことができるとれている。

(7) 中性子束を大きくできるので，ターゲットある いはブランケットに放射性同位元素を置き，その 
寿命を短縮しあるいは安定元琹に変換することに より，原子炬の放射性廃棄物のいわゆる消減処理 に兼用する可能性もある。ただし，消隇処理を有 効に行い得るためには, 再処理, 核抬散防止, 安全 等の多くの関連技術の開発が必要である。今後さ らに実験的研究を行なって，この方式の実用珄の 判断資料を蓄積する必要がある。

一方この方式の問題点には次の上うなむのがある。 (1) 必要とされる大電流の陽子加速器は, 従来の研 究用加速器開発に招い,て技術的問題は汪とんど解 決されているとはいいながら，実際に建設された ことがない。多くの点, 特に取り扱う熱量の点で 前代未聞の加速器である。工業的規模の装置と研 究用装置には大きな違いがあり，史用機の実現ま でにはいくつかの段階的開発が必要で，長期の努 力を要しょう。

（2）陽子のターゲット部分は燃料生産の主要部であ るが，ビーム照射部分とその付近は極めて高温か つ中性子密度が高く、炬といら言莱がふさわし い。しかし，従来の原子炬とは核工学的にも熱工 学的にも全く異なっており, 詳細な計算および実 験的研究を必要とする。

（3）軽水炉の場合のように，他の目的(例えば軍用) で開発された中心的技術がない。巨大技術を最初 から䔩筑することは時間とコストを要することと なる。

(4)この開発研究を行らのに必要な基礎知識を持つ わが国の人員の数は充分とはいえず，開発研究の 過程自体で養成をしなければならない。

以上の利点と欠点を踏を六て各国で検討が行われて 来た。まだ結論を得るに至っていないが，現在の状況 を以下に紹介する。

\section{II . 加速器による核燃料生産および 放射性廃棄物処理方式の概要}

第 2 図に，核然料生産方式の概念図を示す。消隇処

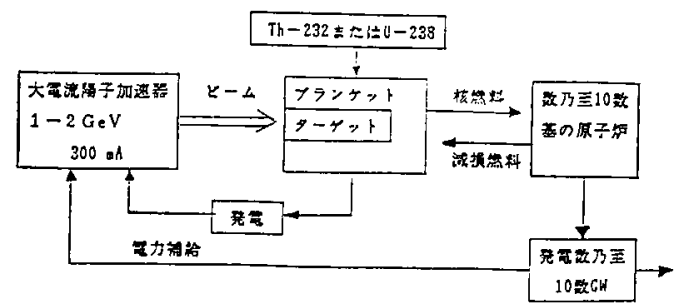

第 2 図加速器による核然料生産方式の概念図
理には，罒のターゲットとブランケットに相当する部 分が使用される。新エネルギーシステムの評価は，関 連するすへての因子を考虑して行われるべきであり， 環境影響などまで含めると多数の項があるが，ここで は範囲を第 2 図の狭い範囲に限って説明する。

\section{1. 陽子加速器}

(1) エネルギー

陽子のスポレーション反応に上り発生する中性子数 は，入射エネルギーとともに增加するからなるべく高 くしたい。一方, 加速器の建設費と維持費, 必要数地 も增加するから劣れには限界がある。1 2 $\mathrm{GeV}$ が必 要かつ充分なェネルギー範围と考えられている。この 值はターゲット系の性能にも依存する。

(2) ビーム電流

$1 \mathrm{GeV}, 300 \mathrm{~mA}$ の電流量に招いて，年間に $1 \mathrm{t}$ 程度 の核分裂性同位元素が得られるとされている。このよ らな大電流は連続動作 $(\mathrm{CW})$ のリンックによらなけ れば実現不可能である。

2. ターゲット系

(1) 中性子収量

入射陽子ビームを中性子に変換する部分であるが， その中性子収量はターゲット元素質量およびターゲッ ト,ブランケット系の構成に传存する。質量が大きい 元索注ど収量が大きい。例点ば ${ }^{238} \mathrm{U}$ は高ェネルギー 陽子，中性子に上る核分裂反応に起因する中性子量が 多い。消隇処理用に分離濃縮したフクチナイド元素を ターゲットに使用できれば収量はさらに大きくなる ら。予想される各種のターゲット材料に対し，発生中 性子のエネルギースペクトル，核種分布，収量あるいは 微分断面積がターゲット系の詳細設計に必要である がまだ充分な実験データが存在しない。各種の理諭 計算式による推定が試みられて部分的な成功を収めて いるが，実用設計に充分とはまだいい難い。組織的な 研究がさらに必要である。

(2) 炉工学的問題

ターゲット内の入射粒子動道近傍と離れた部分とで は，関与する核反応，中性子束密度，熱分布が異なる が，その正確な推定は核反応断面積が小試料について 得られていても,さらに膨大な数值計算を必要とす る。実験により計算結果の検査を行いつつ，逐炊大規 模で複雑な系の推定に進むステップが必要である。

熱密度, 中性子束密度には著しい偏在の生ずる可能 性があり, 熱工学および材料工学的検討を上記と並行 して行う必要があるか，最終的検証には現在稼動中の ものより1〜3桁大さいビーム強度の加速器と大規模 
なモデルターゲット系が必要であろう。

以上のように多くの問題があるため, この部分につ いてはまだ決定的な成案はないが，次のよ5な組み合 やが考えられている。

(1) $\mathrm{Bi} と \mathrm{~Pb}$ の溶融金属流のターダットと ${ }^{238} \mathrm{U}$, ${ }^{232} \mathrm{Th}$ の高融点化合物(炭化物, 酸化物)のブラン rット。

(2) UまたはThの高融点化合物の固体ターゲッ ト牧よびブランケット。ビームの照射面積を大 きくとって融点以上の温度上昇をさけている。 (1), (2)ともブランケットの冷却には高速増殖炉や高 温ガス炉で開発された Na 流体あるいは He ガスの 1 次冾却系を考慮している。ブランケットに固体材料を 用いるこれらの案では，前もって発電炉然料に成形し たものを使用するるのるあるが，大部分は照射後の再 処理,化学分離を前提としているよらである。

(3) U, Th, Be, Li のフッ化物溶融塩をターゲット 兼ブランケット兼 1 次冷媒として使用する一流 体炉の案(3)。

この場合は，然料の放射線損傷および熱除去対策が 容易となりターゲット,ブランヶット系内の材料の シャフリングが自動的に行われる。さらに溶融塩を核 然料兼冷媒とする熱中性子炬，いわゆる高温融体燃料 妒が実用発電灯として使用可能であれば，然料の再処 理,成形工程を必要としないから極めて有利である。

\section{3. 発電师との燃料の交換}

（1）発電炉の炬型の選定

上記の例で理解されるよらに，核然料の生産施設の 具体的な設計は，どのような型の炬を然料の使用先と
するかによりかなり異なってくる。したがってこの 方式の開発研究に扣いては発電炉の炉型の想定が必要 である。例艺ば次のような可能性がある。

(1) 現在の軽水炉の踏襲：加速器炉との燃料の往 復に際して化学再処理や形状の変更が必要なら ば，工程がかなり複雑となる。

（2）新型転換炬(ATR)，カナダ型重水炉(CANDU): 然料加工の問題は上記と同椂であるが，いずれる 然焼効率が良いので, 加速器灯へ然料再生のため に返送する頻度が少ないから，処理工程の問題は 和らげられる。特に ${ }^{232} \mathrm{Th}$ の場合，これから生成

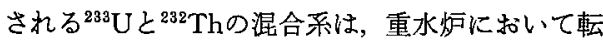
换比 1 に近い熱中性子炉系を形成するので，さら に然焼效率が良いものと期待される。1 基の加速 器炉でこの型の多数の炉の然料供給ができる。カ ナダ原子力公社は CANDUをこの目的に改造す ることを検討している。

(3) 溶融塩炉(MSR)または溶融塩転換炉(MSCR)： この場合は加速器炬飞発電炬々同一組成の燃料を 使用し，減速材のグラファイトの配着の差異によ り連鎖反応の有無を制御する。然料形態の変更が ないから，燃料交換過程は簢単となる。最大の欠 点は溶融塩実用炉がまだ存在しないことである。

\section{4. 放射性廃棄物の消隇処理}

第 1 表に，熱出力 $3,000 \mathrm{MW}$ の核分裂炉を 1 年間運 転した際に蓄積される放射性同位元素のらち，廃棄物 処理問題の重荷となっている核種について, 半減期, 量, 熱中性子捕獲およびスポレーション反応断面積を 記す。

第 1 表 放射性廃棄物核種とその反応断面積

\begin{tabular}{|c|c|c|c|c|c|}
\hline \multirow{2}{*}{ 核 種 } & \multirow{2}{*}{$\begin{array}{c}\text { 半減期 } \\
\text { (yr) }\end{array}$} & \multicolumn{2}{|c|}{ 生成量 ( $3 \mathrm{GWth}-\mathrm{yr}$ ) } & \multirow{2}{*}{$\begin{array}{l}\text { 熱中性子 } \\
\text { 断 面 樻 } \\
\text { (b) }\end{array}$} & \multirow{2}{*}{$\begin{array}{c}\text { 陽子スポレー } \\
シ ョ \text { ン断面穡 } \\
(\mathrm{b}) \\
\end{array}$} \\
\hline & & $(\mathrm{kg})$ & (moles) & & \\
\hline${ }^{90} \mathrm{Sr}$ & 28.1 & 18.1 & 201 & 0.9 & 0.9 \\
\hline${ }^{137} \mathrm{Cs}$ & 30.1 & 41.4 & 302 & 0.11 & 1.2 \\
\hline${ }^{129} \mathrm{I}$ & $1.6 \times 10^{7}$ & - & - & 17.0 & 1.1 \\
\hline${ }^{99} \mathrm{Tc}$ & $2.1 \times 10^{5}$ & 28.3 & 286 & 19.0 & 0.9 \\
\hline${ }^{237} \mathrm{~Np}$ & $2.1 \times 10^{6}$ & $16.6(4.12)$ & $70(17.4)$ & 370 & 1.7 \\
\hline${ }^{241} \mathrm{Am}$ & 433 & $1.2(15.9)$ & $5(66.0)$ & 33 & 1.7 \\
\hline${ }^{243} \mathrm{Am}$ & 7,370 & $2.8(8.3)$ & $11.5(34.2)$ & 70 & 1.7 \\
\hline${ }^{244} \mathrm{Cm}$ & 17.9 & $0.63(0.6)$ & $2.6(2.5)$ & 20 & 1.7 \\
\hline
\end{tabular}

第 1 表のアイントープは核分裂生成物(FP) と中性 子捕獲により生じた超ウランアクチナイド元素に分類 される。Sr-Tc の FP は $\beta$ および $\gamma$ 放射性であり， $\mathrm{Np}-\mathrm{Cm}$ のアクチナイドは $\alpha$ 故射おょび核分裂の崩壊
モードを持ら，FP と異なった毒性評価を要する。ま た，数100年内の蓄積問題で重要な核種（主としてFP） と, 数千～数10万年の長期に残存する核種(主として アクチナイド)に大別できる。消滅処理はとの期間を 
対象とすべきかが明膫にされないと，技術的検討を詳 細に行らことができない。例えば数 100 年内の問題で あ九ば，第 1 表の ${ }^{90} \mathrm{Sr},{ }^{137} \mathrm{Cs}$ かi $\mathrm{Ci}$ 数の大部分を占め るから，それらの変性を考学ねばならない。先の場合 恃熱中性子断面積が小さいから，通常原子炬の中性子 束は処理に有効ではない。

\section{III. 研究開発状況}

現在までの研究開発の過程は継続的というょりは散 発的といら形容が適している。その主たる原因は，最 初のローレンス・リバーモア研究所(LLNL)の大規模な 開発努力が，U資源の発見といら事情で打ち切られた のはやむを得ないにしても，その成果の公開は和ろか， プロシェクトの存在したことさえ公表されず，貴重な 資料と人々の程験が25年間埋もれてしまい，その後米 国でこの問題を再び取り上げる意欲を削いでしまった ためであると思われる。また，軽水炉の目覚ましい成 功と，高速灯和上び核融合方式の早期実用化への希望 が新しい核分致エネルギー源探求の手を控えさせて来 た点もあろう。

1950年代以来，大強度中性子源汇よる核然料の生産 について地味な検討を続けて来たのはカナダのみであ る。バンクーパーのトライフンフ大型サイクロトロ ン，米国の素粒子研究用シンクロトロンを使用して， 高エネルギー陽子によるスポレーション反応の基礎デ 一タを収集するととるに，加速器,ターゲット系の概 念設計を続けて来た。加速器に関しては大型 AVF サ イクロトロン,分離钟道サイクロトロン(SOC)と検討 を続け，連続動作のリニアックを現在は最良としてい
る。1970年代の初めに連続動作電子リニアックを作 り, 半ばに $3 \mathrm{MeV}, 10 \mathrm{~mA}$ の連続動作陽子リニフック を製作し，また $300 \mathrm{kV}, 300 \mathrm{~mA}$ の入射器により大電 流リニアックの基䃈実験を行なって来た。その結果， 従来のパルス動作では表面化しなかった冷却あるいは 高压絶縁物の少化の問題を見出して対策を立ててい る。また,リニフックの全長の大部分を占めてコスト， 電力効率を左右する高 $\beta$ 加速部の開発試作を，口スア ラモス研究所(LANL)と協力して行らとともに，大電 力連続動作クライストロンの開発も試みている。

技術開発と並行して，その経済性解析子行なってい る。その内容は文献(4)に紹介した。それによれば，

(1) 加速エネルギーの $1 \mathrm{GeV}$ 付近でコストが最 小となる。

（2）生産規模が大きい方が $1 \mathrm{~g}$ 当りのコストが小 さくなる。

(3) ${ }^{289} \mathrm{Pu}$ の方が ${ }^{283} \mathrm{U} よ り$ 価格が低い。

（4）作られた核然料は，現在の ${ }^{235} \mathrm{U}(93 \%$ 潜縮)

の価格の約50\$/gよりはるかに高価である。 であって，第 3 图にその計算結果のグラフを示す(5)。 算出されたコストは天然Uの現在の価格が続くなら， 加速器により核然料を作る方式には競争力がないこと を示している。彼らは1990年代末にはU洒格が急騰す るはずで，その際にこの方式が必要となると主張して いる。

米国では長期の中断の後に1971〜 73年頃，原子炉の 放射性廃率物を $1 \mathrm{GeV}$ の大電流陽子リニフックで照 射し処理する万法がブルックヘブン研究所(BNL)で検 討された。その後,関心は核融合师材料試験用の大電

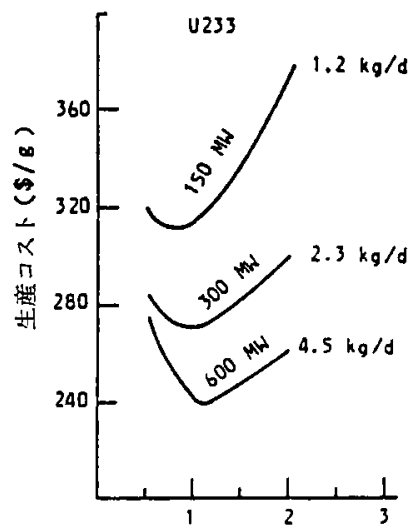

郚子エネルギー (GeV)

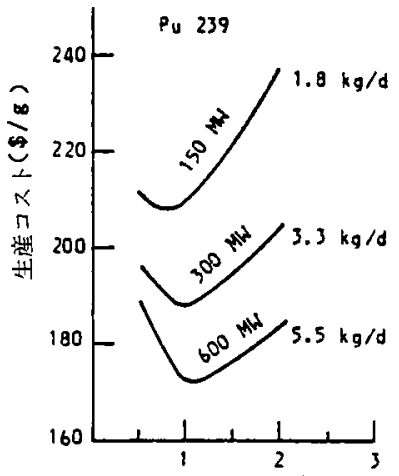

陽子エネルギー $(\mathrm{GeV})$

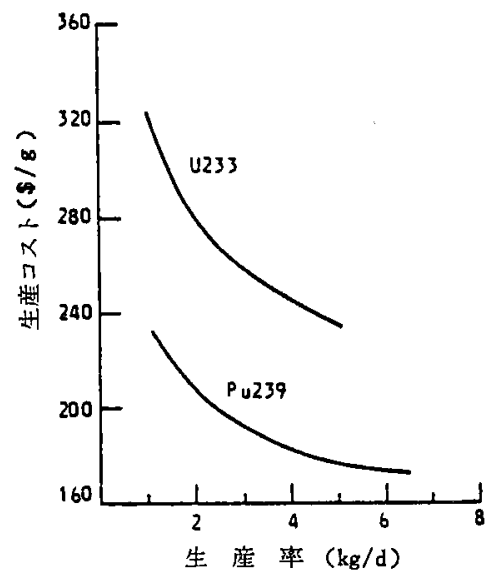

パラメータはビーム西力と 1 日当りの生産量

第 3 図加速器により生産される核燃料のコスト(5) 
流重陽子りニアック施設(FMIT)に移り，35 MeV， $100 \mathrm{~mA}$ のリニアックをLANLが開発してハンフォー ド研究所に建設することに決定, ビーム電力 $3.5 \mathrm{MW}$ の強力中性子源を1990年に完成させる計画が進められ ている。この装置は，加速技術的には，低エネルギー 部分にLANLで開発された RFQ 構造を採用して，入 射電圧を低くしながら大電流の加速軌道捕獲る有効に 行い得ること，主加速部の放射化対策を考慮した機器 および建物設計の点で注目される。

1977年に加速器増殖方式の検討会が BNL で開催さ れ，25年前の LLNL の成果む公表されて，この方式 の米国に拈ける再検討の契機となった。関連技術とし て液体金属 $\mathrm{Li}$ ターゲットを上記の FMIT 計画で開 発しており，その他連続動作大出力管も FMIT，核融 合プラズマ加熱装置, 高ェネルギー加速器, 特に電子蓄 積リング等と䦙逜して, 各種の周波数帯大電力用の開

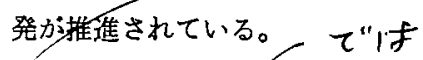
ヨーロッパでは，西独,フランスが1970年代末から 検討を開始してみるが，高速增殖炉，核融合炸に人員 と資金を投》しているためるあり，また大㨁模ではな い。西独 $1.1 \mathrm{GeV}, 10 \mathrm{~mA}$ の大強度陽糸リニアック を建設する計画が進められている。生た，SIN(スィ ス原子核研究所)のサイクロトロン $(590 \mathrm{MeV})$ の平均 電流 $100 \mu \mathrm{A}$ を $2 \mathrm{~mA}$ に増加する改造が1987年に完成す る予定もざらに大電力ターゲット装圆を製作して $10 \mathrm{~mA}$ とする案もある。エネルギー $590 \mathrm{MeV}$ におい

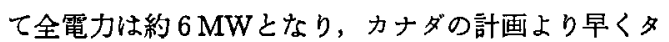
ーゲット炉の試験に使用し得る可能性がある。

わが国では1977年頃から関心を持つクループが誕生 し，小規模な活動を行なっている。ターゲットの核工 学的設計に関しては，米国で開発されたコードを改良
して大容量計算機により中性子束分布を求めて測定值 と比較する作業が行われている。実験值は国外のデー タとともに，筑波の高エネルギー物理学研究所(高工 研)の加速器を使用して, 不足データを補ら努力が1983 年から文部省科研費の補助を得て開始されている。し かし高ェ研の陽子シンクロトロンは同研究所の新加速 器 TRISTAN の工事のため 1983 年度末から停止し, 1985年にならないと運転を再開できないので，充分な データの湘定は85年以降まで待たねばならない。国内 には他に高ェネルギー陽子加速器は存在しないから， 国外の施設の利用あるいは国外の研究者の協力を得て データの蓄皘を図ることが望ましり。国外の施設とる ては，米国LANL の800MeV, $1 \mathrm{~mA} ; \mathrm{LBL} の 730 \mathrm{MeV}$, $0.1 \mu \mathrm{A}$; NASA-SRELの600 $\mathrm{MeV}, 0.05 \mu \mathrm{A}$; IUCPE 200 $\mathrm{MeV}, 10 \mu \mathrm{A}$; カナダバンクーバーの500 MeV, $100 \mu \mathrm{A}$; スイスSINの $590 \mathrm{MeV}, 100 \mu \mathrm{A}(1987$ 年に $2 \mathrm{~mA}) ; \mathrm{CERN}$ の $600 \mathrm{MeV}, 0.1 \mu \mathrm{A}$; フランスサクレーの $3 \mathrm{GeV}$, $1 \mu \mathrm{A}$; 英国 RAL $9800 \mathrm{MeV}, 20 \mathrm{Q} \mu \mathrm{A}$ (建設 中)などが ある。しかし，国際協力を実施し得るためには，わが 国の側にもそれを担当する公的組織が確立されている 必要がある。現在は有志により研究が実施されてはい るが，中心となる機関がないので，継続的な国際協力 の実現は困難であろち。

\section{IV. 可能性検討のための開発作業案}

前章の末尾で述べたよらに，加速器による核然料生 産および放射性廃棄物の処理方式の可能性を検討し, より大きなプロジェクトをわが国が組むべきか否かを 定める作業は，むはや何らかの中心となる組織の指定 ないしは確立がなりれれば，有効な前進は困難な段階に ある。幸いに社会的認知が得られても国外で得られた

第 2 表わが国に打ける関係技術の開発工程詮案

\begin{tabular}{|c|c|c|}
\hline 作業の質 & 期 間 & 作 業 内 容 \\
\hline 基礎的研究 & $5 \sim 10$ 年 & 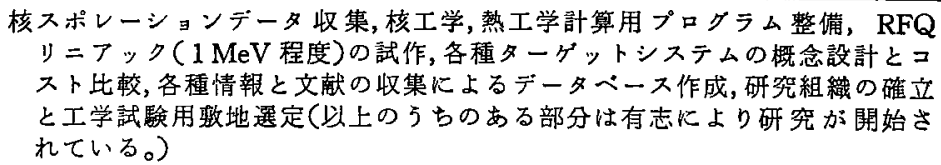 \\
\hline 工学的研究 & $6 \sim 12$ 年 & 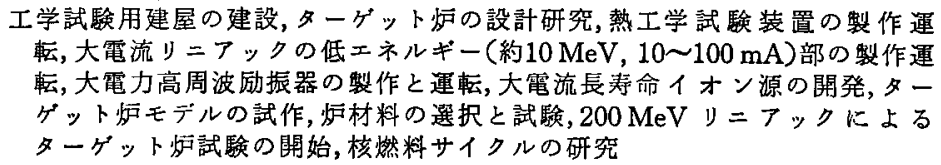 \\
\hline 原型の建設と試験 & $6 \sim 12$ 年 & 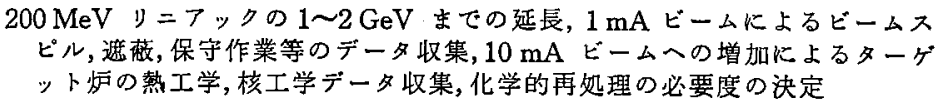 \\
\hline 実証試験期間 & $x$ 年 & $\begin{array}{l}\text { ビーム電流の } 300 \mathrm{~mA} \text { 増強による長時間 運転試験, 各部の改良,発電設備, 熱 } \\
\text { 中性子少の付設による運耺の開始 }\end{array}$ \\
\hline
\end{tabular}


既成技術の導入抁充の場合と異なって，新しいエネル ギー源の可能性の検討には，探索的でありながら組織 的な作業が必要である。各段階ごとに状況を点検し， 計画を改良しつつ進む長期の作業となる。この点 CRNL を中心としたカダの方式は良い参考になる。 天れを参考として，わが国でも開発研究が可能となっ た摖の関保技術の開発工程の試案を仮に作るとすると 第 2 表のよらになるであるら。

以上は討議資料とするための大雑把な案である。実 行組織ができればささらに細分化あるいは巽なった観 点にたった年次計画となるであろう。ここでは，作業 の性格の違いが明瞭となるように分類した。各期間は 相互にオーバーラップが可能であるが，それぞれの作 業で必要とされる予算額も大幅に異なり，次々に 1 桁 に近い増加が予想される。したがって，それぞれが次 の作業の投資の可否検討の資料を提出しなければなら ない。

\section{V.むむび}

加速器による核燃料生産抢よび放射性廃棄物処理方 式は，原理的には明瞭で暧昧な所はない。しかし，そ の実現には社会的認知と, 実用化のための技術開発が 課題として残されている。

本稿では, 技術開発の問題点をいくつかあげたが, その最大のものはターゲット部分の設計である。高エ ネルギービームの入射とスポレーション反応によって
生ずる熱と放射線分布の制御と処理には，核分裂炉と は異なった技術を要する。何種類かのターゲット栬の 概念設計が提出されてはいるが，その可否を核特よび 熱工学的検討で定めるに至っていない。それには，単 純なるのから次第に複雑な構造に至る膨大なシミュレ ーション計算と契験が必要である。最終的には，電流 量は目標値よりはるかに小さくても，エネルギーは充 分に高いビームによる確認実験が必要であろら。一 方, ェネルギーは低くても大電流の加速器を使用して, 材料の熱嗍よび放射線照射下の特性を調べる作業が， 大電流加速器自体の開発と並行してなされることが望 ましい。多面的な研究開発作業る゙統轄する組織がぜひ 必要である。

\section{一荟考文献一}

(1) LivdahL, P.V.: The Livermore MTA project and its influence on modern linacs, Proc. 1981 Linac Conf., Los Alamos, LA-9234-C p.5 (1981).

(2) "Nuclear Energy and Fuel Cycle, Prospects to 2025", p.114 (1982), OECD, Paris.

(3) Furukawa, K., Tsukada, K., Nakahara, Y.: ICANS-IV, Tsukuba, (1980); J. Nucl. Sci. Technol., 18[1], 79 (1981).

FURUKAWA, K.: 3 rd Int. Conf. on Emerging Nucl. Energy Systems, Helsinki, (1983); Atomkernenerg. Kerntech., 44[1], 42 (1984).

(4) 原子力学会「中性子ターゲット」研究専門委(編)：“スポレ ーション中性子工学”，(1984.7月)，印刷中.

(5) Fraser, J.S., HoffManN, C.R., Schribier, S.O., Garvey, P.M., Townes, B.M. : AECL-7260, (1981).

\section{方スポレーション中性子工学々}

\section{「中性子ターゲットシステム」研究専門委員会成果報告書}

1984年 7 月発行予定(限定出版)。予約受付中

B 5 判タイプオフ印刷, 約 250頁, 予価 5,000円(会員特偳 3,500円) (广4400円)

本報告書は，スポレーション中性子発生に関する核物理的基礎理論から，加速器增殖炉の設計 案や加速器の開発課題にわたる広範な検討内容が盛り込まれている。本報告書が会員各位の加速 器の新しい可能性についての関心を高めるとともに，この分野に扣ける研究活動の推進に役立つ ことを期待するものである。

目次 (概 要)

I . 大出力陽子スポレーション加速器の工学的 利用の可能性

(核燃料生産之故射性廃亲物処理の可能性 と経済性, 加速器とターグット開発の現状)

II.ターゲット/ブランケットの核物理・炉物理

(核データ, 二ュートロニクス, 計算法)

III. ターゲット/ブランケット・システムの工学 (加速器増殖炉設計例, 加速器溶融塩
增殖炉, 研究課題)

IV. 大強度陽子シンクロトロンGEMINI と超強力 ハルス中性子源 KENS-II

V. 核然料生産と放射性廃呆物処理のための 加速器

(中間規模加速器, 大強度加速器, 技原開発課題)

○ご希望の方は学会事務局へ。 （予的または10部以上一括の場合は送費無料） 